\title{
Sustainability Models for Efficient Resource Use in the Context of Current Ecological and Social Pressures
}

\author{
Susanne Feiel \\ Resources Innovation Center Leoben, Montanuniversität Leoben, Leoben, Austria \\ Received February 2, 2020; accepted February 4, 2020; published online February 28, 2020
}

\begin{abstract}
The basis of human societal existence is a complex interaction between social, environmental and industrial aspects resulting in the consumption of the environment for wealth generation. In combination with the actual scope of human industrial activity and population development this has led to a currently exceptional planetary situation, which is characterized by unprecedented environmental pressures. In order to develop a strategy on how industrial activity, especially the mineral raw materials sector and its downstream industries, can develop more sustainably, various sustainability models can combined provide orientation on where the journey should go.
\end{abstract}

Keywords: Sustainability, Raw Materials Sector, Sustainable Development Goals, Sustainability Models, Circular Economy

Nachhaltigkeitsmodelle für effiziente Ressourcennutzung im Kontext der gegenwärtigen ökologischen und sozialen Spannungsfelder

Zusammenfassung: Die Basis der menschlichen gesellschaftlichen Existenz wird durch ein komplexes Konstrukt aus Interaktionen zwischen sozialen, ökologischen und ökonomischen Aspekten gebildet. In Kombination mit dem tatsächlichen Ausmaß der gesellschaftlichen Industrieaktivität und des Bevölkerungswachstums hat dies zu einer außergewöhnlichen planetaren Situation geführt, die durch noch nie da gewesene Umweltbelastung charakterisiert ist. Um eine Strategie zur nachhaltigeren Entwicklung des Rohstoffsektors mit seiner Downstream Industrie entwickeln zu können, ermöglichen zahlreiche Nachhaltigkeitsmodelle in Kombination eine Orientierung, wo die Reise hin gehen kann.

\footnotetext{
S. Feiel, BA MA ( $\triangle)$

Resources Innovation Center Leoben,

Montanuniversität Leoben,

Franz-Josef-Straße 18,

8700 Leoben, Austria

susanne.feiel@unileoben.ac.at
}

Schlüsselwörter: Nachhaltigkeit, Rohstoffsektor, Sustainable Development Goals, Nachhaltigkeitsmodelle, Kreislaufwirtschaft

\section{The Basis of Human Societal Existence and its Status Quo}

In the way the human societal system has developed, a minimum amount of wealth is required for everybody to obtain a certain minimum life standard that at the very least ensures sufficient nutrition, health, education and housing and as a result leads to human capacity development ([1, 2]; Fig. 1).

To generate this wealth, economic activity, or more specifically industrial activity is needed. The basis for this are raw materials, such as minerals and metals. "They form the backbone of modern economies and are key to providing wealth services to citizens around the globe such as housing, mobility and communication. Sustainability transitions such as the energy system transformation and megatrends such as digitization pose extra requirements on the world economy's raw material supply" [3]. The raw materials industry and its downstream industry are therefore the backbone industrial sector of human wealth.

Raw Materials need to be obtained from the environment's natural capital [4], meaning that the environment provides the industry with relevant provisioning ecosystem services [5] but that at the same time the environment is being consumed. For their very existence humans are dependent on the environment and its natural capital for ecosystem services like the supporting service for soil formation, nutrient cycling and biodiversity but also others like the regulating and cultural service. Society's existence and its interconnected industrial activity for wealth generation thus need the environment while at the same time consuming it.

These interconnections in combination with the actual scope of human industrial activity and existence have currently led to an exceptional planetary situation, which is characterized by unprecedented environmental pressures. 
Fig. 1: Wealth Creation Interdependency Triangle, Susanne Feiel. (c) Susanne Feiel

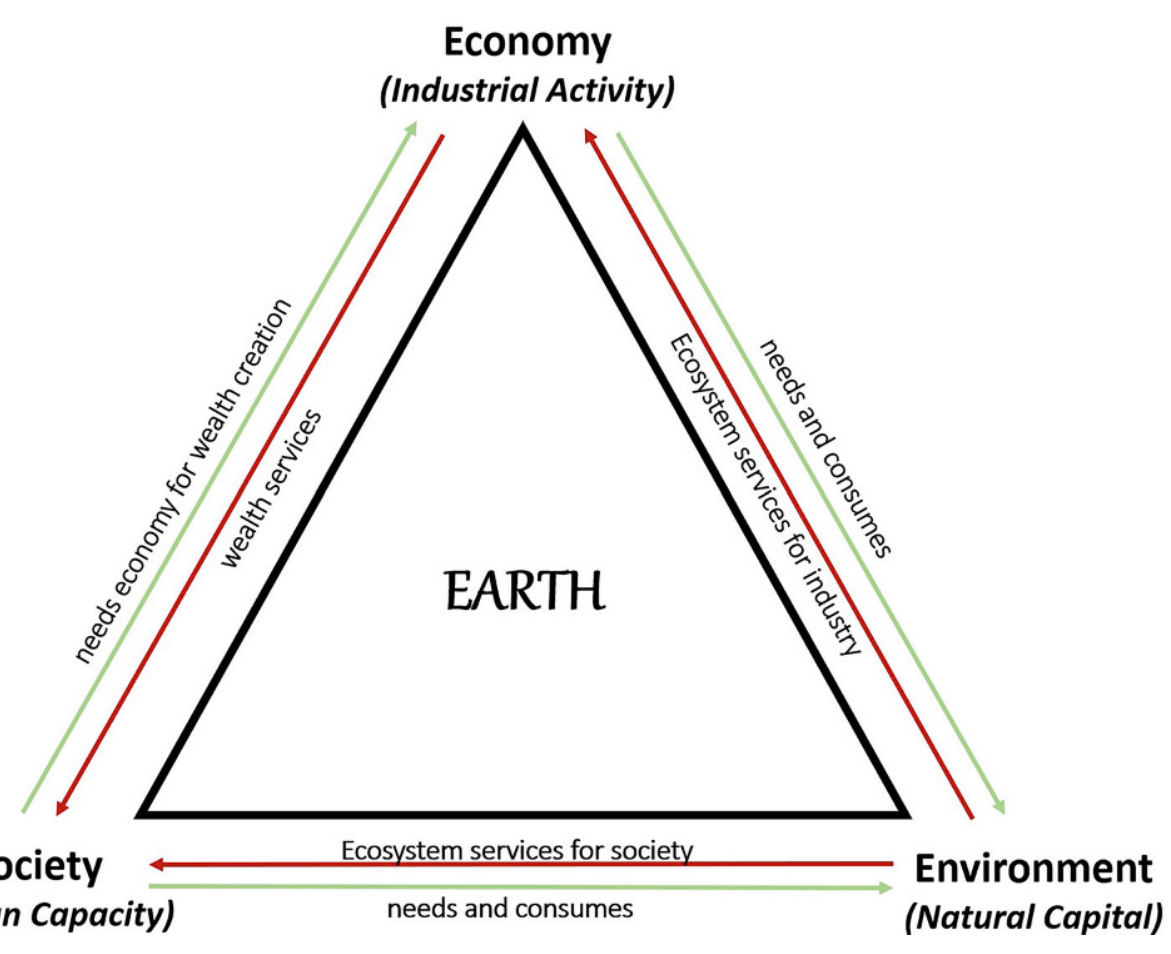

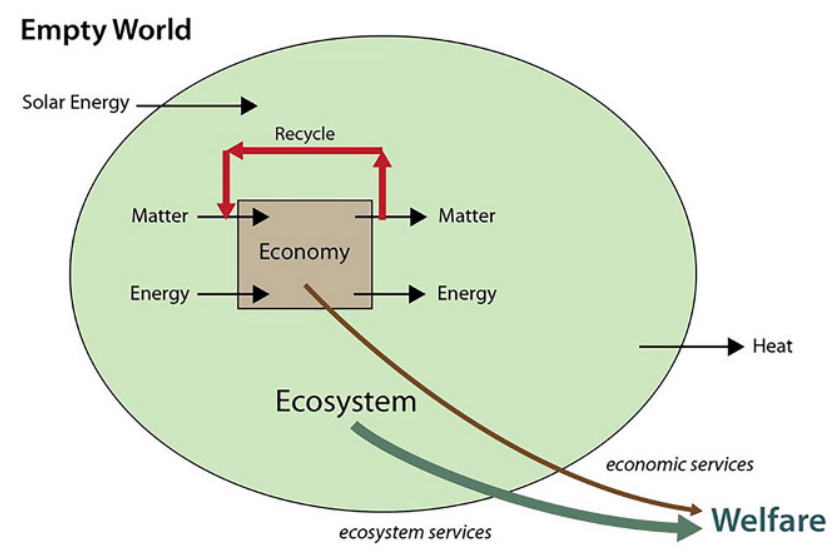

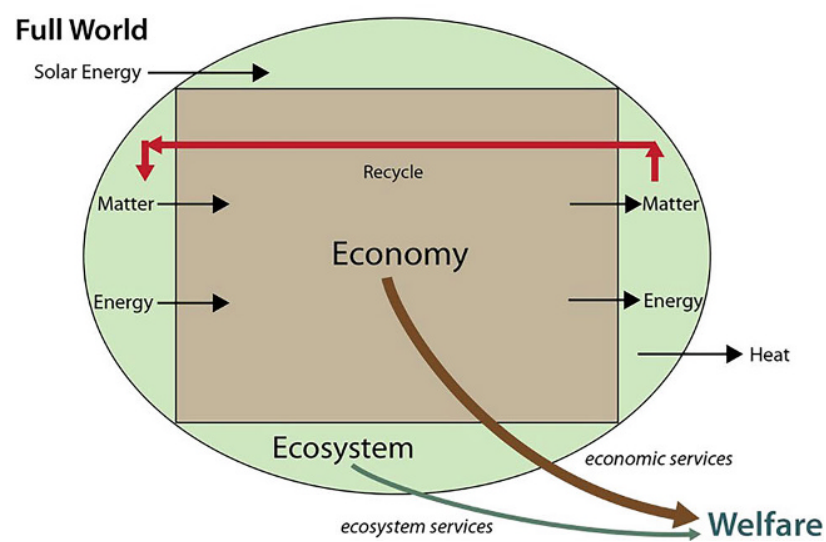

Fig. 2: Full World vs. Empty World, Herman Daly, https://greattransition. org/publication/economics-for-a-full-world (Accessed 09.12.2019)
Population growth has drastically increased by unbelievable 6.5 billion over the past 120 years [6]. Close to 8 billion people live on the planet today, all of them striving for economic well-being for a better social life. When the economic system came into being some 100 years ago its industrial activities were insignificant to the planet [7] compared to the existing large ecological reality. Environmental impacts were thus easily absorbed. Only a small fraction of the total population drove industrial activity. (Fig. 2).

Today society is still under the impression of living in such an empty world where nature is endless, with only a small population fraction driving the economy, but actually since then the world has become very full with a human-nature ratio that does not leave much space. Thus the most common socio-economic and earth system trends have been increasing, meaning not only GDPs and wealth, but $\mathrm{CO}_{2}$, methane, ocean acidification, surface temperatures, domesticated land, water use, fertilizer consumption, international tourism, etc. As a result, $75 \%$ of all planetary terrestrial surface has already been altered by humans, $85 \%$ of all wetlands have been lost and $25 \%$ of all species are endangered, with a risk of extinction within the next 10 years [8]. All these trends have started or accelerated since about 1900. (Fig. 3).

This human-driven impact even brought about a whole new geological age called the Anthropocene, an age in which human-driven activity has become mightier than geological force in driving ecologic and planetary change [9].

Although this human imprint brings along negative effects for the planet, it results in positive dynamics for individual human lives. "Since the mid-twentieth century, global economic development has already helped many millions of people worldwide escape deprivation and for many, this transformation has been accompanied 


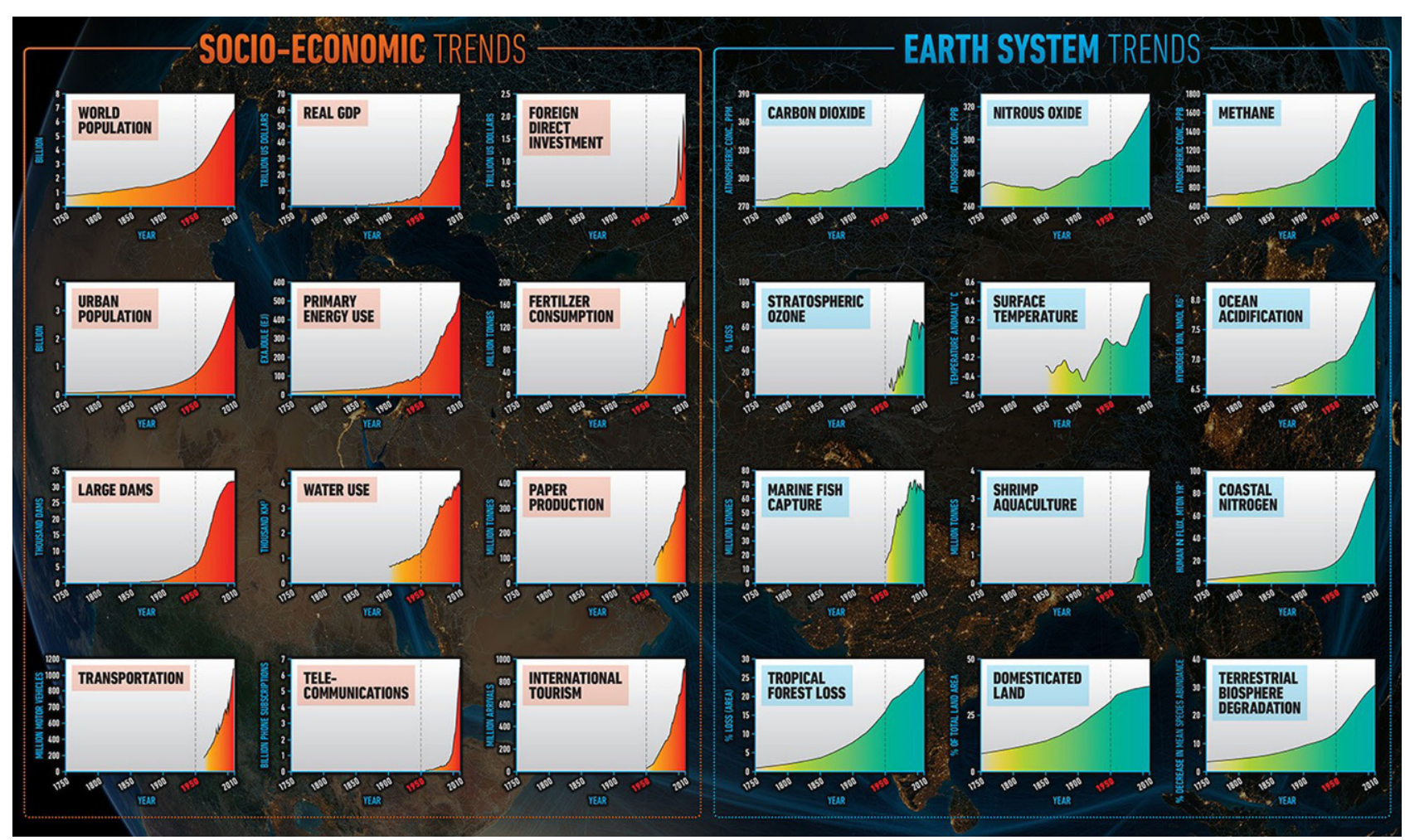

Fig. 3: The Great Acceleration Trends [22]

by greater equality between women and men, and a greater political voice" [10].

Whether good or bad, "the dominant feature of socioeconomic trends is that the economic activity of the human enterprise [overall still] continues to grow at a rapid rate" [9]. Additionally, population growth is still drastically increasing, projected to stabilize at around 11.2 billion only in 2100 [11]. Furthermore, raw materials demand has strongly increased across all types, leading to unprecedented extraction, supply and sustainability issues. Statistics confirm that raw materials demand has risen from 43 billion metric tons in 1990 to 92 billion in 2017 and with current trends and no concerted political action, a projected growth to 190 billion in 2060 [12]. For the moment population and economic growth cannot be reversed and the question that remains is how to relieve the environment despite these trends.

\section{The Road to Sustainable Industrial Development}

To develop a strategy on how the mentioned industrial activity can develop more sustainably, firstly general sustainability theory and its possible contribution should be scrutinized to see what it can do for the endeavor.

The most familiar sustainability model is the three-pillar model, an omnipresent understanding of sustainability, placing ecology, economy and social matters at its core as three equally weighty foundations. (Fig. 4).

It has been criticized as too empty, that "a consequence of the lack of rigor in [its] theoretical underpinnings [...]

is the difficulty in producing operational frameworks for the characterization of sustainability which remain rooted in theory. Such applications would [...] have to be context specific, requiring both spatial and functional boundaries" [13]. In this sense, relevant spatial and functional frameworks for specific applications need to be developed but can be based on this.

The model does not acknowledge, however, that the environment is the service provider for industrial and social activity as all three pillars are equally weighted. In contrast, the discussion around weak and strong sustainability does acknowledge this. The theory of weak sustainability rests upon the assumption that "we can purchase ManMade Capital with infinite and abundant Natural Capital", asserting that "man-made-resources can substitute natural resources" [14]. Strong sustainability on the other hand, per definition has the environment as basis for economic and societal activity as a non-substitutable factor [15], one of the reasons being e.g. that the consumption of natural capital is usually irreversible as for instance with species extinction [16]. The environment is in fact the basis of human

Fig. 4: The Three Pillars of Sustainability, https://www. thwink.org/sustain/glossary/ ThreePillarsOfSustainability. htm (Accessed 09.12.2019)

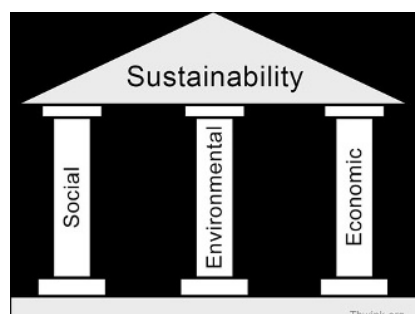


Fig. 5: The Planetary Boundaries of Stockholm Resilience Center, https://www. stockholmresilience.org/ research/research-news/ 2015-01-15-planetaryboundaries---an-update. html (Accessed 09.12.2019)

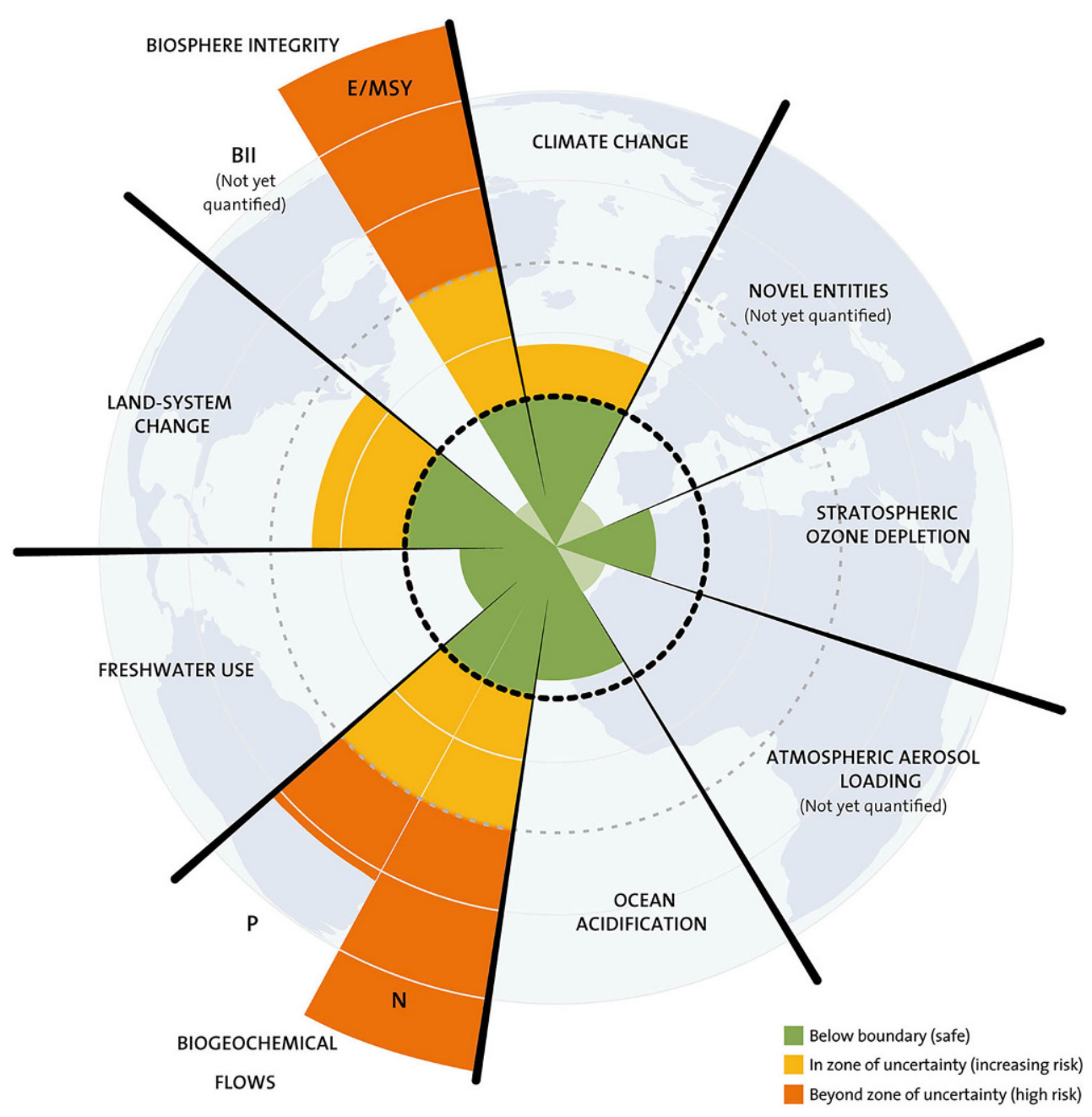

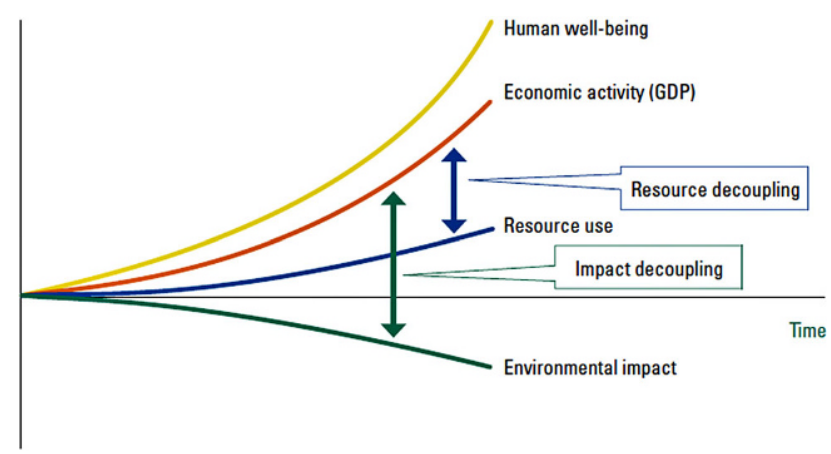

Fig. 6: The Two Aspects of Decoupling, UNEP 2011, Decoupling Natural Resource Use and Environmental Impacts from Economic Growth

existence and industrial activity and once it has reached its final capacity, there is nothing more positive to gain for the economy and society.

In fact, this is mirrored in The Planetary Boundaries, a set of identified naturally existing limits which "define a safe operating space for humanity based on the intrinsic biophysical processes that regulate the stability of the Earth System." Overstepping them may lead "[... to the beginning of global ecosystem imbalances, the results of which are unknown" with the risk of "abrupt or irreversible environmental changes that would be deleterious or even catastrophic for human well-being" ([17]; Fig. 5).

The current status is that three boundaries have been transgressed with negative outlooks. They need to be guiding indicators in all industrial processes.

A fairly new framework are the UN Sustainable Development Goals-SDGs - in which countries mobilize efforts to balance the environmental, social and economic dimensions of human development to ensure a sustainable future for all people by decoupling industry's environmental impact from its economic activity, the key concept meaning "two things: decoupling economic growth from resource consumption ('resource decoupling') and from environmental impacts ('impact decoupling')" [18]. (Fig. 6).

The three sustainability pillars are equally weighted in the framework, so the underlying notion follows a weak sustainability approach. After all, the agenda follows the original concept of the Brundtland report in which economic growth is seen as the solution to achieve human well-being and solve environmental problems. However, the concept appears worthy of a closer look.

The question is how this decoupling can take place in the raw materials and its downstream industry. 
SDG 12, Responsible consumption and production with its target $12.2-$ by 2030 achieve sustainable management and efficient use of natural resources seems to have a relevant specific scope and guiding potential. The UN [19] and EUROSTAT [20] have developed indicators to measure the progress of its implementation inside the EU, but these are only quantitative. They do not reflect qualitative aspects of production processes that reflect or influence globally spread raw materials value chains. Clearly, reduced output of something does not automatically imply it is qualitatively more sustainable. The question is thus, how this relevant target can be populated with a qualitative indicator framework for sustainable raw materials value chain production processes that will thus decouple.

As opposed to popular perception, circular economy cannot provide the key to solving the problem as due to several restraints such as in-stock use, required material qualities, required energy input, complex material composition, material loss etc. [21] it will never be able to completely supply the system with the needed raw materials through secondaries. It will be part of the solution, anyhow, if cleverly designed. In any case, it has led science to look at materials in their individual production and consumption and reproduction and re-consumption path which can serve as a valuable contributor to design qualitative life cycle system boundary frameworks.

\section{Conclusion}

It has become clear that part of the solution of how to decouple environmental impact from industrial production is the development of system, functional and spatial boundaries and populate them with qualitative framework indicators that reflect the environment as basis of all processes. Spatial boundaries according to the circular economy should comprise analyses for each individual material cycle. According to the critique of general sustainability theory, functional boundaries should be established through a delimitation of each individual production step inside any of these material cycles. Within each of these production steps then qualitative indicators like the planetary boundaries should be applied, ensuring that no production step negatively influences the biophysical equilibrium. Functional-boundary-interface management is of further crucial importance as it will ensure the handing over of materials from one production step to the next is realized with due diligence in terms of environmental care. Concerning spatial boundaries, it is important to spatially place raw materials production and its downstream industry somewhere where it is possible to control the system and its functions. In this way, an option to decouple impact for Europe is to increase local production. This is not only important in terms of environmental aspects but in terms of social aspects, namely who we want to be as a society. It is time that we take responsibility for our own consumption behavior and make sure that our extensive wealth creation activities do not harm other people and the environment somewhere else anymore.
Funding. Open access funding provided by Montanuniversität Leoben.

Open Access This article is licensed under a Creative Commons Attribution 4.0 International License, which permits use, sharing, adaptation, distribution and reproduction in any medium or format, as long as you give appropriate credit to the original author(s) and the source, provide a link to the Creative Commons licence, and indicate if changes were made. The images or other third party material in this article are included in the article's Creative Commons licence, unless indicated otherwise in a credit line to the material. If material is not included in the article's Creative Commons licence and your intended use is not permitted by statutory regulation or exceeds the permitted use, you will need to obtain permission directly from the copyright holder. To view a copy of this licence, visit http://creativecommons.org/licenses/by/4.0/.

\section{References}

1. Caring Economy Campaign: Social Wealth Economic Indicators, http://caringeconomy.org/newindicators/\#\%E2\%80\%9D (05.11.2019)

2. United Nations Development Programme: About human development, http://hdr.undp.org/en/humandev (12.11.2019)

3. Umwelt Bundesamt: Raw materials and the environment, https:// www.umweltbundesamt.de/en/raw-materials-environment-2019start (09.12.2019)

4. World Forum on Natural Capital: What is natural capital, https:// naturalcapitalforum.com/about/ (09.12.2019)

5. European Commission (Ed.): Science for Environment Policy: Ecosystem Services and Biodiversity, Issue 11, Bristol: DG Environment, 2015. In-depth report 11 produced for the European Commission by the Science Communication Unit, UWE, available at http://ec.europa.eu/science-environment-policy (09.12.2019)

6. Our World in Data: Population growth, https://ourworldindata.org/ world-population-growth (09.12.2019)

7. Daly, H.: Economics for a full world, https://greattransition.org/ publication/economics-for-a-full-world (30.11.19)

8. Intergovernmental Science-Policy Platform on Biodiversity and Ecosystem Services-IPBES: Brondizio, E. S. et al. (Eds): Global assessment report on biodiversity and ecosystem services of the Intergovernmental Science-Policy Platform on Biodiversity and Ecosystem Services, Bonn: IPBES secretariat, 2019

9. Steffen, W.; Broadgate, W.; Deutsch, L.; Gaffney, O.; Ludwig, C. The trajectory of the Anthropocene: The Great Acceleration, The Anthropocene review, 2 (2015), iss.1, pp 81-98

10. Raworth, K.: Doughnut Economics, 1. ed., London: Random House, 2018

11. United Nations: World Population Prospects, https://www.un.org/ development/desa/publications/world-population-prospects-the2017-revision.html (09.12.19)

12. United Nations Statistics Division: SDG 12, https://unstats.un.org/ sdgs/report/2019/goal-12/ (09.12.19)

13. Purvis, B.; Mao, Y., Robinson, D.: Three pillars of sustainability: In search of conceptual origins, Sustainability Science, 14 (2019), iss. 3, pp 681-695, doi https://doi.org/10.1007/s11625-018-0627-5

14. Abreu, N.: Pennsylvania State University: Weak sustainability, https://www.e-education.psu.edu/eme504/node/7 (09.12.2019)

15. Neumeyer, E.: Weak vs. Strong Sustainability: Exploring the limits of two opposing paradigms, Cheltenham: Edgar Elgar Publishing, 2003

16. Pelenc, J.; Dedeurwaerdere, T.: Brief for the Global Sustainable Development Report-GSDR 2015: Weak Sustainability versus Strong Sustainability, https://sustainabledevelopment.un.org documents (09.12.19)

17. Rockstrom, J. et al.: Planetary boundaries: exploring the safe operating space for humanity, Ecology and Society, Vol. 14 (2009), iss.2, art. 32, URL:http://www.ecologyandsociety.org/vol14/iss2/ art32/ (09.12.19)

18. United Nations: The Sustainable Development Goals, http://www. un.org/sustainabledevelopment/development-agenda/ (09.12.19)

19. United Nations Statistics Division: SDG Indicators Goal 12, https:// unstats.un.org/sdgs $/$ metadata/?Text $=\&$ Goal $=12 \&$ Target $=12.2$ (09.12.19) 
20. Eurostat (Ed.): Sustainable development in the European Union, Luxembourg: Publications Office of the European Union, 2018

21. Moser, P.; Feiel, S.: Raw Materials as a Driver of Economic Growth and Job Creation in the Transition to an Innovation-driven Lowcarbon and Circular Economy, BHM Berg- und Hüttenmännische Monatshefte 164 (2019), Nr. 4, S. 156-158

22. https://www.nationalgeographic.org/projects/out-of-eden-walk/ galleries/2015-03-trajectory-anthropocene-great-acceleration/. Accessed 25.02.2020

Publisher's Note. Springer Nature remains neutral with regard to jurisdictional claims in published maps and institutional affiliations. 